\title{
PERENCANAAN JARINGAN AKSES MOBILE WiMAX (WORLDWIDE INTEROPERABILITY FOR MICROWAVE ACCESS) 2,5 GHz UNTUK WILAYAH DKI JAKARTA
}

\author{
Hesti Susilawati, ST., MT. ${ }^{1}$ Widhiatmoko HP, ST $^{2}$ Dimass Noly Mardhiko ${ }^{3}$ \\ Program Studi Teknik Elektro, Fakultas Sains dan Teknik, Universitas Jenderal Soedirman \\ ${ }^{1}$ hesti_s@yahoo.co.id, ${ }^{2}$ aries_whp001@yahoo.com, ${ }^{3}$ local_geniuscool@yahoo.com
}

\begin{abstract}
ABSTRAK
Standar IEEE 802.16e yang dikenal dengan mobile WiMAX adalah standar broadband wireless access (BWA) yang beroperasi pada frekuensi 2 - $6 \mathrm{GHz}$. Standar ini merupakan pengembangan dari standar WiMAX sebelumnya untuk mendukung mobilitas pengguna. Pada penelitian ini, penulis melakukan perhitungan untuk memprediksi kebutuhan bandwidth untuk pelanggan mobile WiMAX di wilayah DKI Jakarta untuk jangka waktu tiga tahun sejak WiMAX diimplementasikan. Kebutuhan bandwidth ini akan digunakan untuk menentukan jumlah base station yang dibutuhkan dari sisi kapasitas. Penulis juga melakukan perhitungan jumlah base station dari sisi coverage menggunakan persamaan Erceg. Dari hasil perhitungan tersebut, dapat disimpulkan bahwa pada tiga tahun pertama penetrasi WiMAX di Jakarta, kebutuhan jumlah base station dari sisi coverage lebih besar dari pada perhitungan dari sisi kapasitas.
\end{abstract}

Kata kunci : Mobile WiMAX, bandwidth, base station, kapasitas, coverage

\begin{abstract}
IEEE 802.16e Standard, known as WiMAX Mobile, is a standard forBroadband Wireless Access (BWA) operating in the frequency band of $2-6 \mathrm{GHz}$. This standard, which is the evolution of the previous WiMAX Standard, is established to support mobility. In this Final Project the calculation is made to forecast the requirement of bandwidth for WiMAX users in the area of DKI Jakarta for the planning horizon of three years since the beginning of the program deployment. The bandwidth forecast will be applied to determine the number of Base Stations required to meet the capacity standpoint. Meanwhile from the coverage standpoint, the writer uses Erceg Formula to calculate the number of Base Stations.From the outcome of the calculation process, it comes to a conclusion that for the first three years of the WiMAX deployment in Jakarta, the number of Base Stations based on the coverage standpoint is larger than that based on the capacity standpoint.
\end{abstract}

Keyword : Mobile WiMAX, bandwidth, base Station, capacity, coverage 


\section{PENDAHULUAN}

Perkembangan zaman dan teknologi akhirakhir ini membuat kebutuhan manusia akan transfer dan akses informasi, baik itu voice, data ataupun video menjadi sangat besar. Oleh karena itu diciptakan suatu teknologi baru yaitu Worldwide Interoperability for Microwave Access (WiMAX). WiMAX merupakan standar yang dikembangkan oleh grup IEEE 802.16. Pada bulan Desember 2005, IEEE mengeluarkan standar IEEE 802.16e yang dikenal sebagai Mobile WiMAX yang merupakan amandemen standar sebelumnya untuk mendukung aplikasi Mobile.

Rumusan masalah yang kita kaji adalah merencanakan jaringan yang optimal, merencanakan kebutuhan bandwidth, merencanakan jumlah base station yang dibutuhkan untuk melayani pelanggan Mobile WiMAX.

Dari rumusan masalah yang telah disampaikan dapat diketahui bahwa tujuan penelitian ini adalah untuk memperkirakan kebutuhan bandwidth dan mengetahui jumlah base station untuk melayani pelanggan WiMAX dalam penelitian.

Hasil akhir dari penelitian ini mudahmudahan dapat memberikan penjelasan mengenai kebutuhan bandwidth dan jumlah base station yang dibutuhkan untuk mencakup seluruh wilayah DKI Jakarta agar dapat melayani pelanggan Mobile WiMAX.

\section{TINJAUAN PUSTAKA}

\subsection{Mobile WiMAX}

Mobile WiMAX yang berdasar standar IEEE 802.16e memungkinkan sistem WiMAX diterapkan pada aplikasi portable dan mobile maupun fixed dan nomadic. Mobile WiMAX memperkenalkan teknologi Orthogonal Frequency Division Multiple Access (OFDMA) dan mendukung beberapa fitur lain untuk menyediakan layanan mobile broadband bagi pengguna. Fitur-fitur tersebut adalah:

a. Toleransi pada multipath dan selfinterference dengan ortogonalitas subkanal,baik untuk downlink maupun uplink,

b. Scalable channel bandwidth dari1,25 sampai $20 \mathrm{MHz}$,

c. Time Division Duplex (TDD) memberikan efisiensi yang mendukung trafik asimetris.

\subsection{OFDM dan OFDMA}

\subsubsection{Orthogonal Frequency Division}

\section{Multiplexing}

Orthogonal Frequency Division Multiplexing (OFDM) merupakan suatu sistem multicarier yang membagi spektrum frekuensi ke dalam sejumlah subcarrier berpita sempit. Pada sistem multicarrier seperti OFDM, stream data input dibagi ke dalam sejumlah substream paralel, dimana masing-masing stream dikirim dan dimodulasikan melalui subcarrier terpisah yang saling ortogonal. 


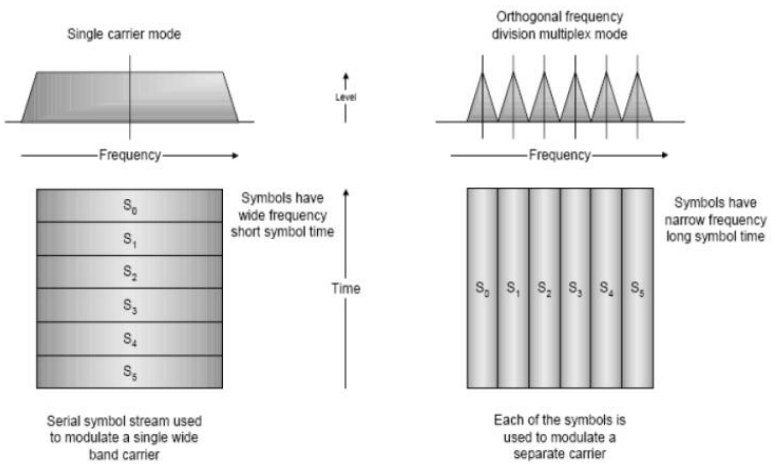

Gambar 1 Perbandingan Sistem Carrier Tunggal dengan sistem Multicarrier

\subsubsection{Orthogonal Frequency Division}

Multiple Access

Pada sistem OFDM, sumber daya yang dapat digunakan dibagi dalam domain waktu (simbol OFDM) dan domain frekuensi (subcarrier). Pada mobile WiMAX, beberapa subcarrier dikelompokkan menjadi suatu subchannel untuk dialokasikan kepada pengguna. Sistem tersebut disebut Orthogonal Frequency Division Multiple Access (OFDMA). OFDMA adalah skema yang memungkinkan proses multiplexing pada aliran data dari beberapa pengguna.
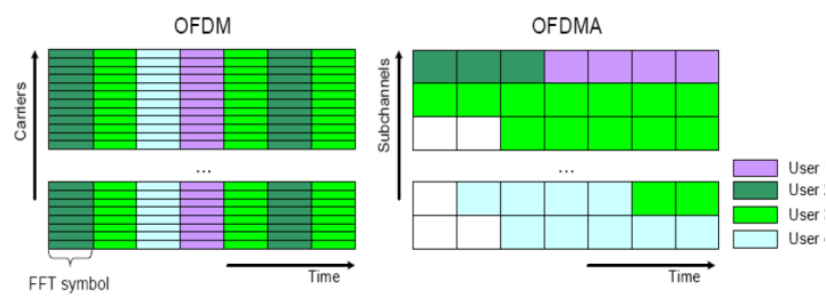

Gambar 2 Perbedaan antara OFDM dengan OFDMA

Struktur simbol OFDMA terdiri dari tiga tipe subcarrier, yaitu:

a. Data subcarrier yang digunakan untuk transmisi data, b. Pilot subcarrier yang digunakan untuk etimasi dan sinkronisasi,

c. Null subcarrier yang berfungsi sebagai guard band dan DC carrier dan tidak digunakan untuk transmisi.

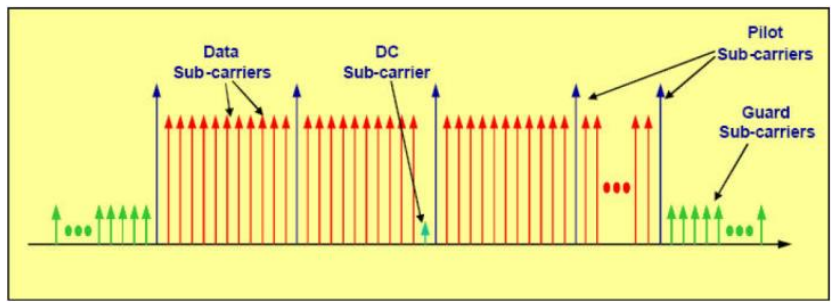

Gambar 3 Struktur Subcarrier OFDMA

\subsection{Model Propagasi Erceg}

Model propagasi digunakan untuk memprediksikan kuat sinyal rata-rata pada suatu tempat dengan jarak tertentu dari transmitter. Oleh karena itu, model propagasi berperan penting dalam perencanaan jaringan wireless terutama untuk menentukan coverage suatu base station.

Model Erceg diperoleh dari hasil eksperimen terhadap 95 buah makrosel di Amerika Serikat pada frekuensi kerja 1,9 GHz. Model ini diadopsi oleh IEEE 802.16 sebagai model yang direkomendasikan untuk aplikasi broadband. Model Erceg berlaku pada keadaan berikut.
a. $1900 \mathrm{MHz} \leq \mathrm{f} \leq 3500 \mathrm{MHz}$
b. $10 \mathrm{~m} \leq \mathrm{h}_{\mathrm{b}} \leq 80 \mathrm{~m}$
c. $0,1 \mathrm{~km} \leq \mathrm{d} \leq 8 \mathrm{~km}$

Berdasarkan terrain, model Erceg dibagi menjadi 3 jenis, yaitu: 
a. Tipe A : daerah perbukitan dengan densitas pepohonan sedang sampai tinggi,

b. Tipe B : daerah perbukitan dengan pepohonan jarang atau daerah rata dengan densitas pepohonan sedang,

c. Tipe $\mathrm{C}$ : daerah rata dengan densitas pepohonan yang rendah.

Persamaan umum model Erceg adalah

$$
\mathrm{PL}=\mathrm{A}+10_{\gamma} \log 10\left(\frac{\mathrm{d}}{\mathrm{d}_{0}}\right)+\Delta \mathrm{PL}_{\mathrm{f}}+\Delta \mathrm{PL}_{\mathrm{h}}+\mathrm{s}
$$

Keterangan:

a. $\mathrm{A}=$ free space path loss yang dinyatakan dengan

$$
A=20 \log _{10}\left(\frac{4 \pi d_{0} f}{c}\right)
$$

b. $\gamma=$ path loss exponent yang dinyatakan dengan

$$
\gamma=\mathrm{a}-\mathrm{bh}_{\mathrm{b}}+\frac{\mathrm{c}}{\mathrm{h}_{\mathrm{b}}}
$$

c. $\Delta \mathrm{PL}_{\mathrm{f}}=$ faktor koreksi untuk penggunaan frekuensi

$$
\Delta \mathrm{PL}_{\mathrm{f}}=6 \log _{10}\left(\frac{\mathrm{f}}{1900}\right)
$$

d. $\Delta \mathrm{PL}_{\mathrm{h}}=$ faktor koreksi tinggi antena penerima pada

berbagai kondisi terrain dengan $\mathrm{h}_{\mathrm{m}}$

dalam meter

$$
\Delta \mathrm{PL}_{\mathrm{h}}=-10.8 \log _{10}\left(\frac{\mathrm{h}_{\mathrm{m}}}{2}\right)
$$

untuk terrain tipe A \& B

$$
\Delta \mathrm{PL}_{\mathrm{h}}=-20 \log _{10}\left(\frac{\mathrm{h}_{\mathrm{m}}}{2}\right)
$$

untuk terrain tipe $\mathrm{C}$ e. $d=$ jarak antara antena pemancar dengan penerima $(\mathrm{m})$

f. $\mathrm{d}_{0}=100$ meter

g. $\mathbf{s}=$ perubahan acak yang terdistribusi secara lognormal sebagai representasi shadowing

h. $\mathrm{h}_{\mathrm{b}}=$ tinggi antena base station

i. $\mathrm{a}, \mathrm{b}, \mathrm{c}=$ konstanta digunakan untuk menghitung path loss exponent $\gamma$ dan besarnya tergantung pada tipe terrain

Tabel 1 Parameter Model Erceg

\begin{tabular}{|c|c|c|c|}
\hline Parameter & Terrain A & Terrain B & Terrain C \\
\hline A & 4,6 & 4 & 3,6 \\
\hline B & 0,0075 & 0,0065 & 0,005 \\
\hline C & 12,6 & 17,1 & 20 \\
\hline
\end{tabular}

(Sumber : Wireless Physical Layer Concepts, Prof.Raj Jain, 2008)

\subsection{Prosedur Perencanaan Jaringan}

Dalam prosedur perhitungan kebutuhan bandwidth terbagi menjadi beberapa tahap, antara lain:

1. Melakukan perhitungan kebutuhan shared bandwidth atau kebutuhan bandwidth untuk aplikasi data yang tidak sensitif terhadap delay seperti internet browsing. Perhitungan shared bandwidth dilakukan terhadap tiga jenis,yaitu:

a. Prosedur Perhitungan Shared bandwidth untuk pelanggan residensial

$j$ mlh pelanggan residensial $=\frac{j \text { mlhpenduduk }}{4} \times \%$ pelanggan

Bandwidth $($ Mbps $)=j$ mh pelanggan residensial. $\times \frac{\text { keceppatan akes }}{1024} \times$ OSF

b. Prosedur Perhitungan Shared bandwidth untuk pelanggan corporate 


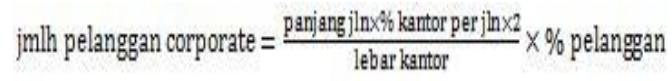

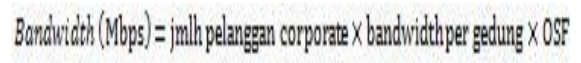

c. Prosedur Perhitungan Shared

bandwidth untuk pelanggan personal

i. Pemukiman

jmlh pelanggan personal $=0,61 \times j$ mlh penduduk $\times \%$ pelanggan

Bandwidth $($ Mbps $)=j$ mlh pelanggan personal $\times \frac{\text { kecepptan akses }}{1024} \times$ OSF

ii. Jalan Padat Aktivitas

jmlh plnggn personal $=\frac{\text { pning jnx } \times \text { knt } / \text { jlnx } \times 2}{\text { lebarkntr }} \times j$ mlh pegawai $/$ kntr $\times \%$ plnggn

2. Melakukan perhitungan bandwidth untuk kebutuhan voice atau layanan telephony. Perhitungan ini menggunakan teori trafik Erlang. Jumlah kanal yang dibutuhkan untuk melayani seluruh pelanggan kemudian dikonversi menjadi kebutuhan bandwidth. Hasil penjumlahan kebutuhan shared bandwidth dengan kebutuhan voice merupakan bandwidth total yang diperlukan suatu wilayah untuk estimasi waktu tiga tahun.

Intensitas trafik per user $=\lambda \times \mathrm{h}$

Intensitas traf ik per user = Intensitas tra fik per user $\times$ pengguna layanan voice

Jumlah sel $=\frac{\text { Total shared bandwidth }}{\text { bandwidth yang dapat ditangani oleh satu sel }}$

Intensitas trafik per sektor $=\frac{\text { Intensitas trafik total }}{3 \times \text { jumlah sel }}$

bandwidth voice per sektor $=$ Jumlah kanal yang diperlukan $x \frac{\text { kecepatan akses }}{1024}$
Total bandwidth voice $=$ Bandwidth voice per sektor $\times 3 \times$ jumlah sel

Total bandwidth $=$ Total shared bandwidth + total bandwidth voice

3. Menentukan jumlah base station yang dibutuhkan berdasarkan besar bandwidth total. Dengan persamaan sebagai berikut:

jmlh base station $=\frac{\text { bandwidthtotal }}{\text { bandwidth persel }}$

4. Menentukan lokasi base station berdasarkan kebutuhan bandwidth setiap daerah. Parameter penting pada perhitungan shared bandwidth adalah oversubscription factor (OSF).

\section{METODE PENELITIAN}

\subsection{Tahapan Penelitian}

Penelitian yang penulis lakukan bersifat studi literatur terhadap jurnal-jurnal dan teori yang kiranya mendukung penulisan ini. Adapun untuk tahap penelitiannya adalah sebagai berikut

i. Tahapan Pengumpulan Data

Dalam penelitian ini, penulis mengambil materi penelitian mengenai Perencanaan Jaringan Akses Mobile WiMAX. Parameterparemeter yang diamati terbagi beberapa tahap, yaitu sebagai berikut :

1. Jumlah penduduk per kecamatan di wilayah Jakarta,

2. Jumlah pelanggan WiMAX di wilayah Jakarta,

3. Jumlah gedung di jalan padat aktivitas,

4. Jumlah tiap ruas panjang jalan di wilyah DKI Jakarta. 
ii. Tahapan Pengolahan Data

Pada tahapan ini, semua data yang sudah dikumpulkan akan diolah untuk memperoleh tujuan penelitian dengan rincian sebagai berikut :

1. Merencanakan dan Menentukan daerah layanan,

2. Menentukan cakupan daerah layanan dengan memperhatikan jumlah pelangan dan tipe pelanggan,

3. Menentukan teknologi yang akan digunakan,

4. Menentukan alokasi frekuensi pada jaringan WiMAX.

iii. Tahap Analisis Data

Pada tahap ini, data yang sudah diolah akan diterapkan dalam perencanaan dengan melakukan analisis atau perhitungan sebagai berikut:

1. Melakukan perhitungan kebutuhan shared bandwidth yang dilakukan terhadap tiga jenis pelanggan yaitu:

a. Kebutuhan shared bandwidth pelanggan Residensial. Dengan persamaan (7) dan (8).

b. Kebutuhan shared bandwidth pelanggan Corporate. Dengan persamaan (9) dan (10).

c. Kebutuhan shared bandwidth pelanggan

Personal

i. Pemukiman

Dengan persamaan (11) dan (12).

ii. Jalan Padat Aktivitas
Dengan persamaan (13).

2. Melakukan perhitungan bandwidth untuk kebutuhan voice atau layanan telephony. Perhitungan ini menggunakan teori trafik Erlang. Dengan persamaan (14), (15), (16), (17), (18), (19), dan (20).

3. Menentukan jumlah base station yang dibutuhkan berdasarkan besar bandwidth total. Dengan persamaan (21).

iv. Tahap Akhir

Merupakan tahap paling akhir dari laporan yaitu penulisan laporan dan seminar hasil penelitian.

\subsection{Diagram Alur Penelitian}

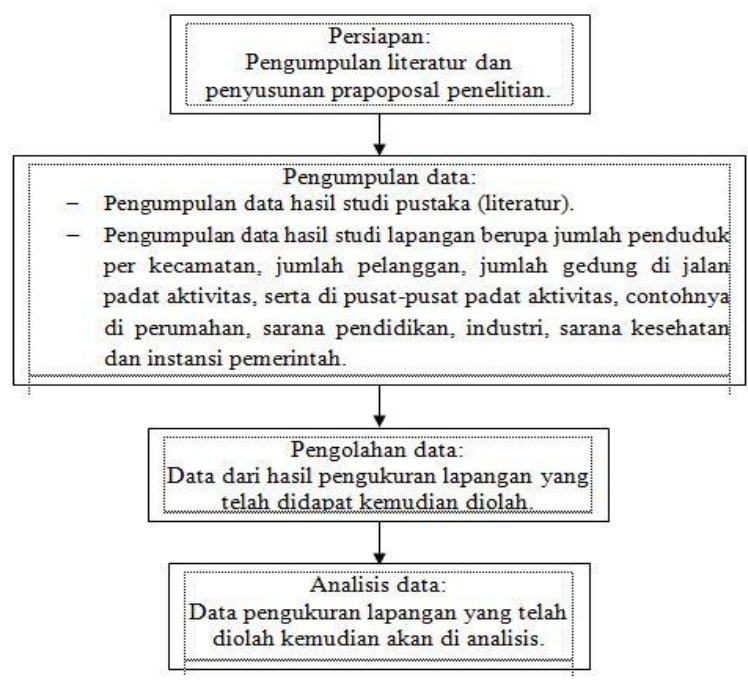

Gambar 4 Diagram Alur Penelitian 


\section{HASIL DAN PEMBAHASAN}

\subsection{Perhitungan Kebutuhan Shared}

\section{Bandwidth}

\subsubsection{Kebutuhan Shared Bandwidth \\ Pelanggan Residensial}

Sebagai contoh perhitungan, digunakan Kecamatan Menteng dengan jumlah penduduk 70.772 orang. Kecamatan Menteng terdiri dari rumah-rumah mewah sehingga diasumsikan persentase pelanggannya sebesar $15 \%$ dari total rumah di kecamatan tersebut.

$$
\begin{gathered}
\text { jmlh pelanggan residensial }=\frac{70.772}{4} \times 0,15 \\
=2.654 \text { rumah }
\end{gathered}
$$

Sehingga shared bandwidth yang dibutuhkan Kecamatan Menteng adalah

\section{Bandwidth (Mbps)}

$$
\begin{aligned}
&= 2.654 \times \frac{384}{1.024}(\mathrm{Mbps}) \\
& \times \frac{1}{20} \\
&=49,7625 \mathrm{Mbps}
\end{aligned}
$$

Data bandwidth yang dibutuhkan untuk pelanggan residensial di kecamatan lainnya dapat dilihat pada grafik berikut.

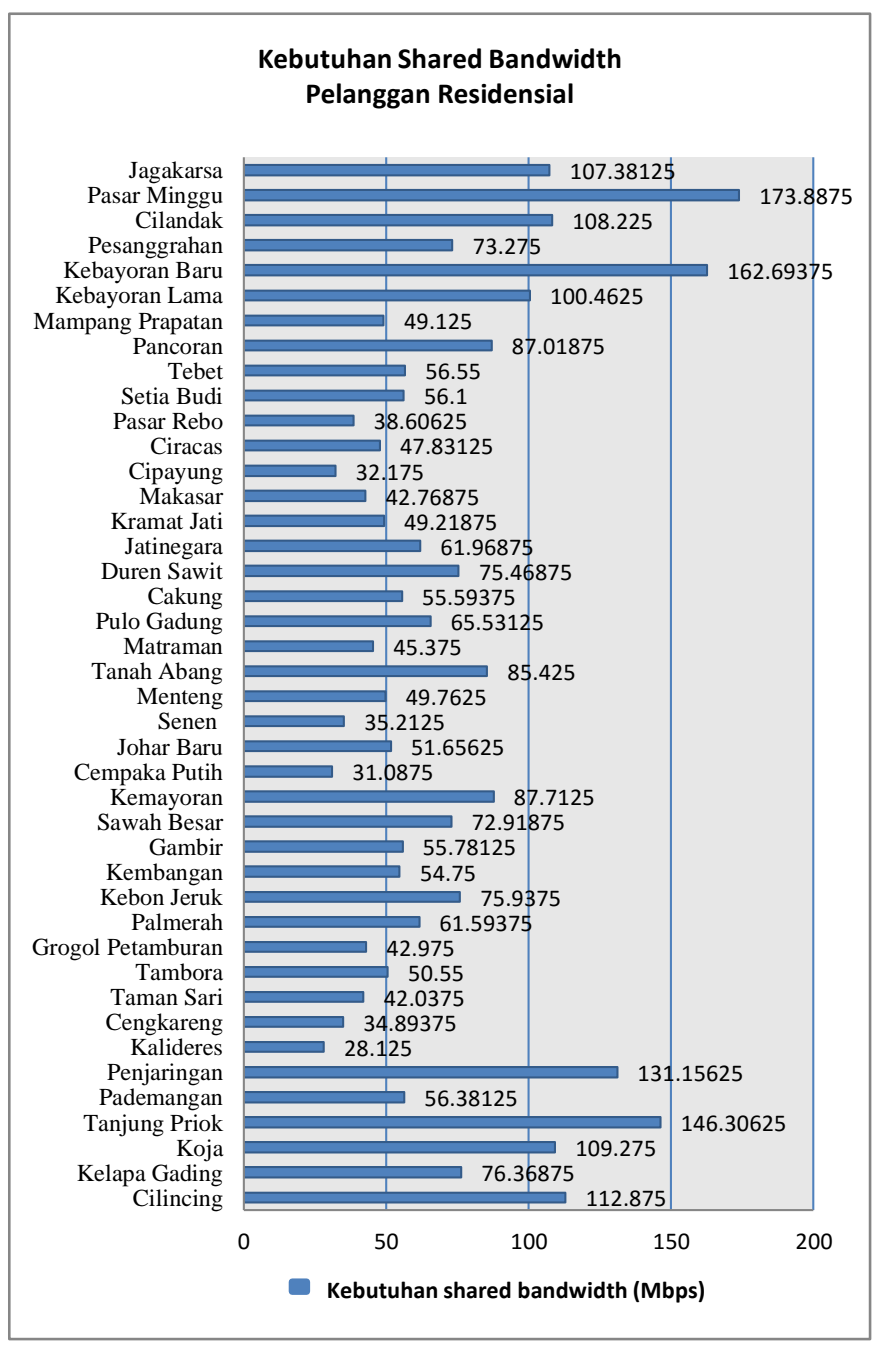

Gambar 5 Grafik Kebutuhan Shared Bandwidth Pelanggan Residensial per Kecamatan

Dari gambar grafik di atas diketahui bahwa total shared bandwidth pelanggan residensial adalah 2.982,0375 Mbps.

\subsubsection{Kebutuhan Shared Bandwidth Pelanggan Corporate}

Sebagai contoh perhitungan, digunakan Jalan Gatot Subroto yang termasuk dalam kawasan segitiga emas. Di kawasan segitiga emas, persentase jalan yang digunakan sebagai gedung perkantoran adalah $80 \%$ dari keseluruhan jalan tersebut. Selain itu juga 
diasumsikan bahwa satu gedung terdiri dari 15 kantor dan setiap kantornya membutuhkan 2 Mbps, maka total bandwidth yang dibutuhkan per gedung adalah $30 \mathrm{Mbps}$.

jmlh pelanggan corporate

$$
\begin{gathered}
=\frac{6.996 \times 0,8 \times 2}{70} \times 0,25 \\
=40 \text { gedung }
\end{gathered}
$$

Shared bandwidth yang dibutuhkan Jalan Gatot Subroto adalah

$$
\begin{gathered}
\text { Bandwidth }(\mathrm{Mbps})=40 \times 30 \times \frac{1}{10} \\
=12 \mathrm{Mbps}
\end{gathered}
$$

Data bandwidth yang dibutuhkan untuk pelanggan corporate di jalan padat aktivitas lainnya dapat dilihat pada grafik berikut.

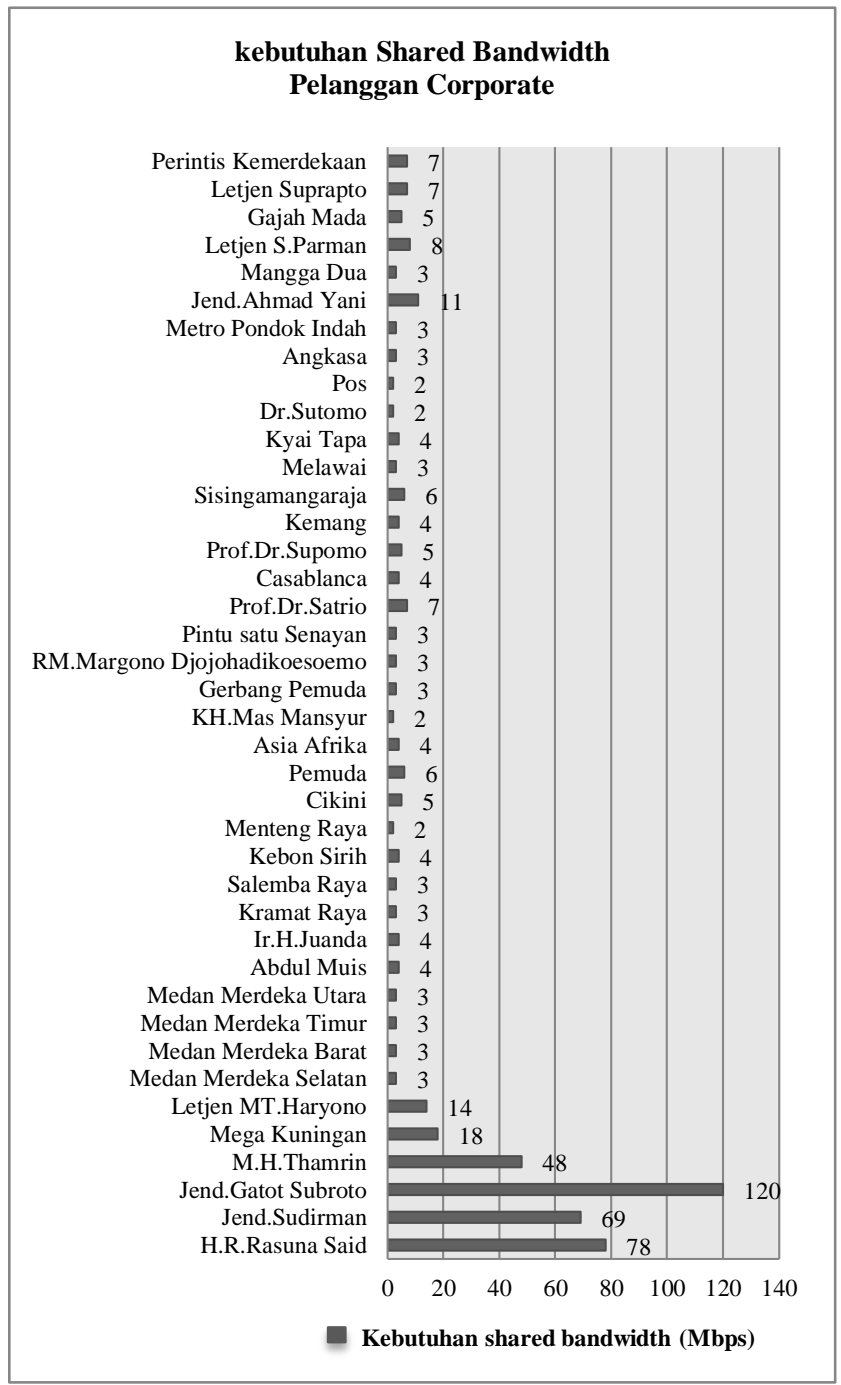




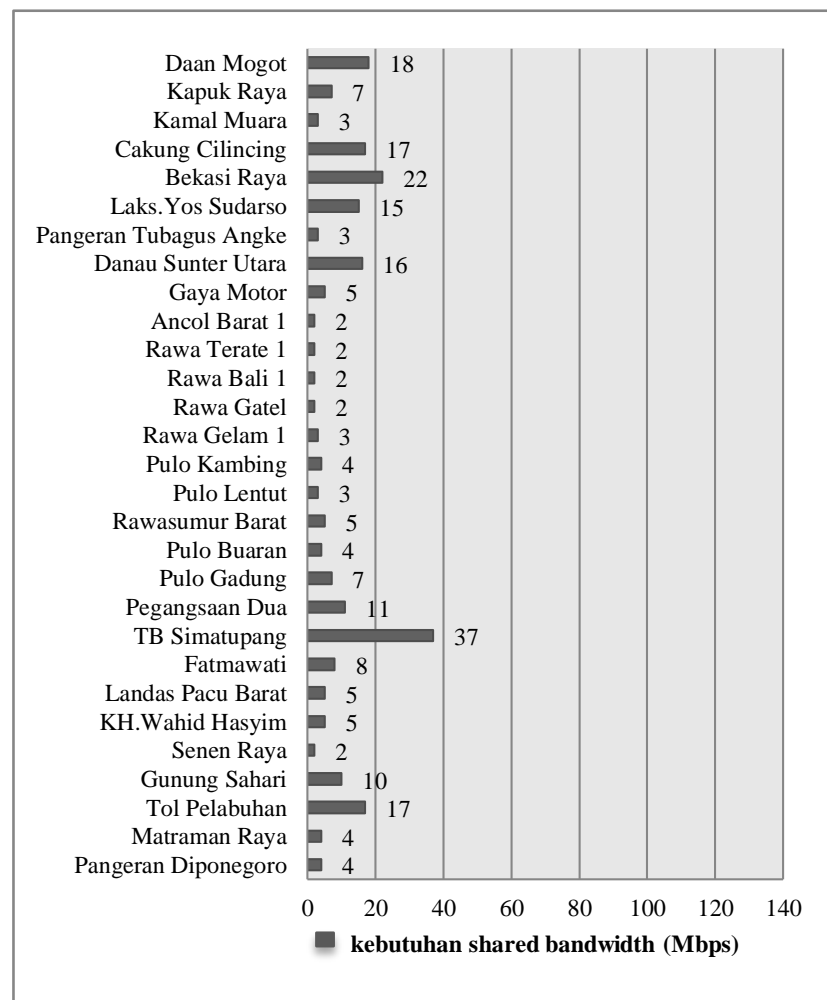

Gambar 5 Grafik Kebutuhan Shared Bandwidth Pelanggan Corporate pada Jalan Padat Aktivitas

Dari gambar grafik di atas diketahui bahwa total shared bandwidth pelanggan corporate adalah 732 Mbps.

\subsubsection{Kebutuhan Shared Bandwidth}

\section{Pelanggan Personal}

\subsubsection{Kebutuhan Shared Bandwidth \\ Pelanggan Personal di Wilayah Permukiman}

Sebagai contoh perhitungan, digunakan Kecamatan Menteng yang merupakan kawasan permukiman mewah, sehingga dapat diasumsikan bahwa jumlah penduduk yang berlangganan mobile WiMAX sebesar 20\% dari jumlah penduduk yang berpotensi menggunakan WiMAX. jmlh pelanggan personal

$$
\begin{aligned}
& =0,61 \times 70.772 \times 0,2 \\
& =8.634 \text { pelanggan }
\end{aligned}
$$

Sehingga shared bandwidth yang dibutuhkan Kecamatan Menteng untuk pelanggan personal adalah

\section{Bandwidth (Mbps)}

$$
\begin{aligned}
& =8.634 \times \frac{256}{1.024}(\mathrm{Mbps}) \times \frac{1}{30} \\
& =71,95 \mathrm{Mbps}
\end{aligned}
$$

Data bandwidth yang dibutuhkan untuk pelanggan personal di Kecamatan lainnya dapat dilihat pada grafik berikut.

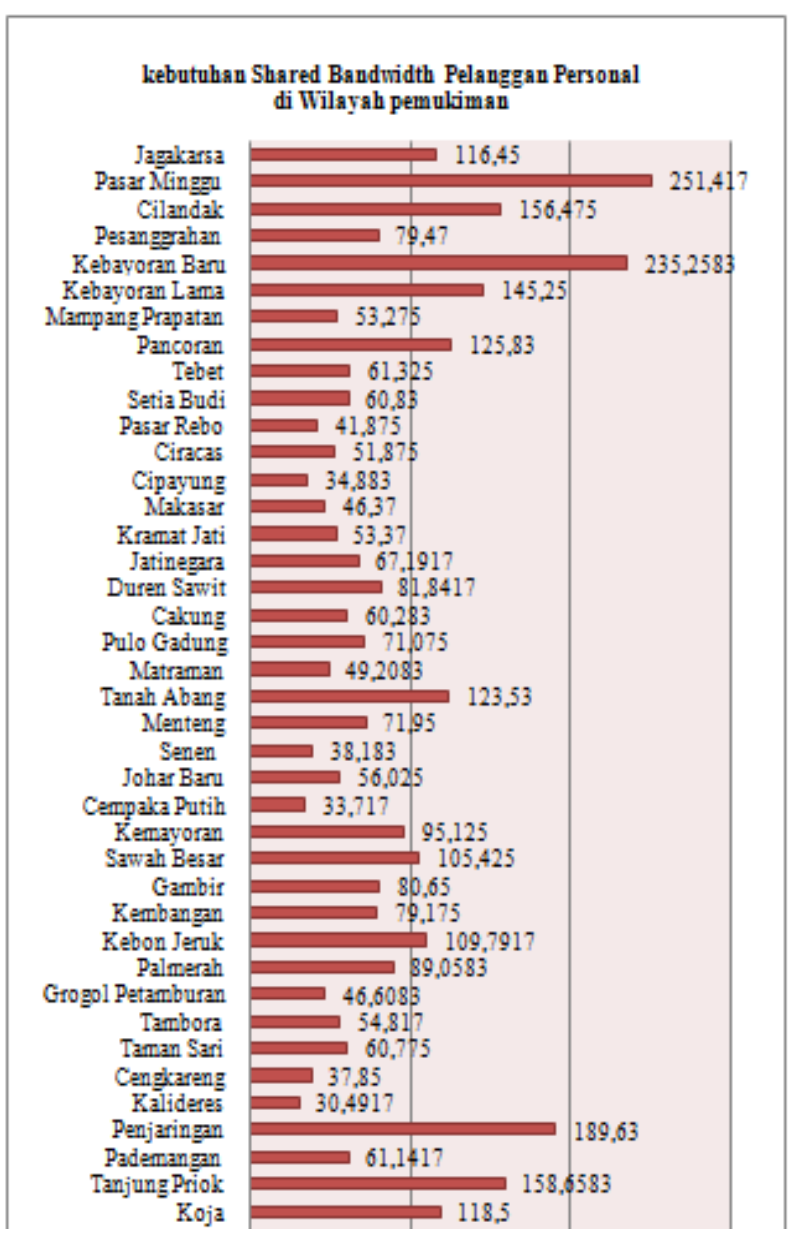




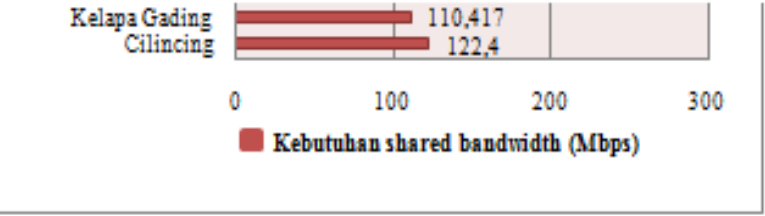

Gambar 6 Grafik Kebutuhan Shared Bandwidth Pelanggan Personal di Wilayah Permukiman per Kecamatan

Dari gambar grafik di atas diketahui bahwa total shared bandwidth untuk pelanggan personal di wilayah permukiman adalah $3.717,472$ Mbps.

\subsubsection{Kebutuhan Shared Bandwidth}

\section{Pelanggan}

\section{Personal di Jalan Padat Aktivitas}

Sebagai contoh perhitungan, digunakan Jalan Gatot Subroto yang termasuk dalam kawasan segitiga emas. Di kawasan segitiga emas, persentase jalan yang digunakan sebagai gedung perkantoran adalah $80 \%$ dari keseluruhan jalan tersebut. Diasumsikan dalam satu gedung terdapat 750 pegawai dan $20 \%$ di antaranya berlangganan mobile WIMAX.

jmlh plnggn personal

$$
\begin{aligned}
& =\frac{6.996 \times 0,8 \times 2}{70} \times 750 \\
& \times 0,2 \\
& =23.986 \text { pelanggan }
\end{aligned}
$$

Bandwidth (Mbps)

$$
\begin{aligned}
& =23.986 \times \frac{256}{1.024}(\mathrm{Mbps}) \times \frac{1}{30} \\
& =199,8833 \mathrm{Mbps}
\end{aligned}
$$

Data bandwidth yang dibutuhkan untuk pelanggan personal di jalan padat aktivitas lainnya dapat dilihat pada grafik berikut.

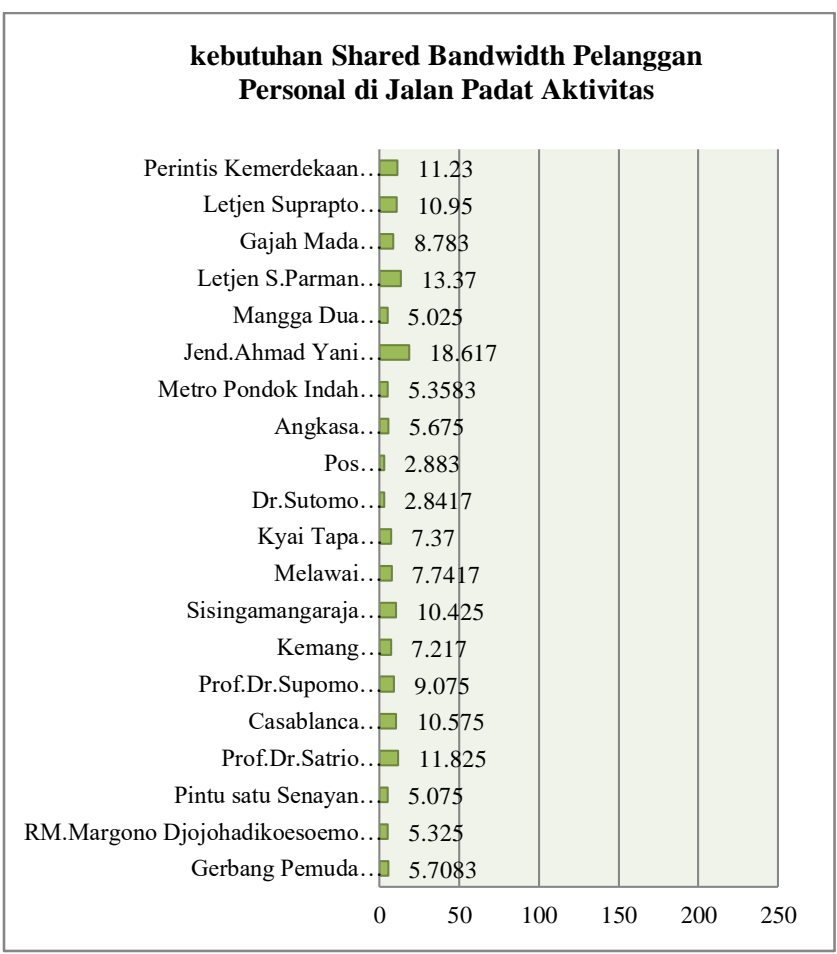

Sehingga shared bandwidth yang dibutuhkan Jalan Gatot Subroto untuk pelanggan personal adalah 


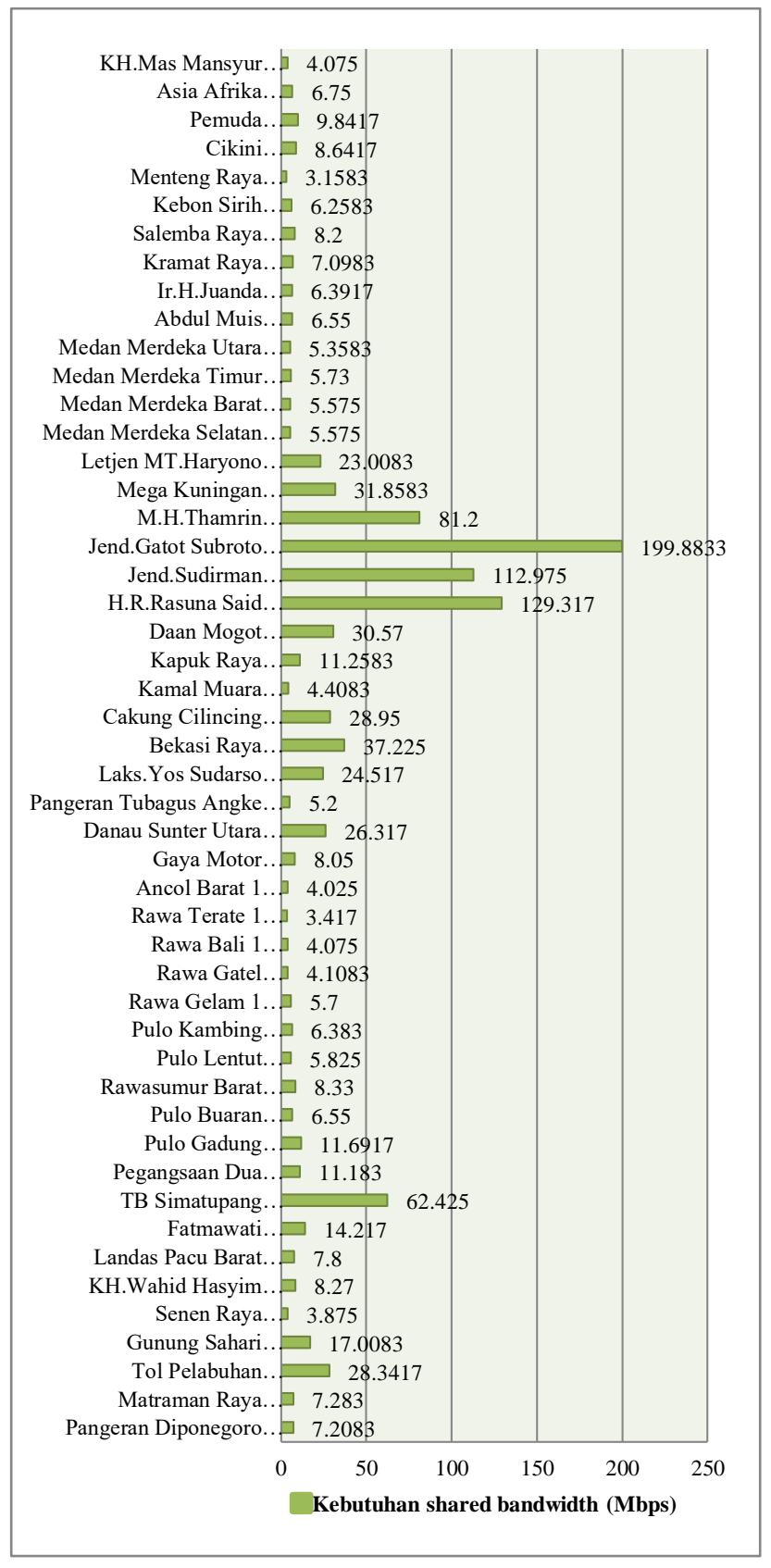

Gambar 7 Grafik Kebutuhan Shared Bandwidth Pelanggan Personal di Jalan Padat Aktivitas

Dari gambar grafik di atas diketahui bahwa total shared bandwidth untuk pelanggan personal di jalan padat aktivitas adalah 1.236,7271 Mbps.

\subsubsection{Kebutuhan Shared Bandwidth Daerah}

\section{Khusus}

Sebagai contoh perhitungan, digunakan daerah khusus Taman Mini Indonesia Indah (TMII) dengan Jumlah pengunjung pada jam sibuk adalah 5.000 orang. Potensi pengguna WiMAX adalah 50\% dari pengunjung karena sekitar 50\% pengunjungnya adalah anak-anak yang belum termasuk dalam kelompok usia yang berpotensi menggunakan WiMAX. Pelanggan WiMAX adalah $20 \%$ dari total potensi pengguna.

$$
\begin{aligned}
& \text { jmlh plnggn daerah khusus } \\
& \qquad \begin{aligned}
= & 5.000 \times 0,5 \times 0,2 \\
& =500 \text { pelanggan }
\end{aligned}
\end{aligned}
$$

Sehingga shared bandwidth yang dibutuhkan Taman mini indonesia indah (TMII) untuk daerah khusus adalah

Bandwidth (Mbps)

$$
\begin{aligned}
& =500 \times \frac{256}{1.024}(\mathrm{Mbps}) \times \frac{1}{30} \\
& =4,167 \mathrm{Mbps}
\end{aligned}
$$

Data bandwidth yang dibutuhkan untuk daerah khusus lainnya dapat dilihat pada grafik berikut. 


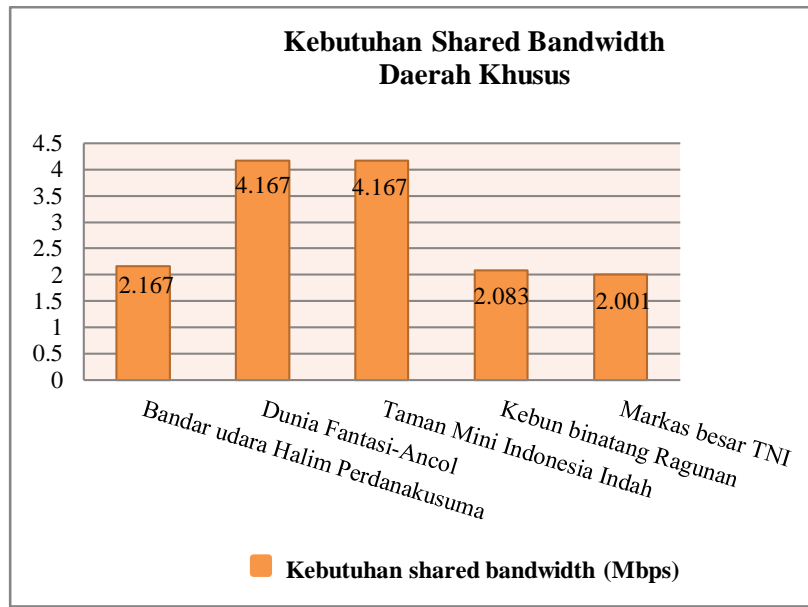

Gambar 8 Grafik Kebutuhan Shared Bandwidth

Daerah Khusus

Dari grafik di atas diketahui bahwa Shared Bandwidth Daerah Khusus berbeda-beda, ini dikarenakan jumlah pengunjung tiap daerah khusus tidak sama. Walaupun hanya Dunia Fantasi-Ancol dan Taman Mini Indonesia Indah yang Shared Bandwidth sama, karena asumsi yang digunakan untuk jumlah pengunjung di daerah ini sama. Jadi total shared bandwidth untuk pelanggan di daerah khusus adalah 14,585 Mbps.

Berdasarkan data kebutuhan bandwidth pelanggan residensial adalah 2.982,0375 Mbps, pelanggan corporate adalah 732 Mbps, pelanggan personal adalah 4.954,1991 Mbps, dan kebutuhan bandwidth daerah khusus adalah 14,585 Mbps, maka total shared bandwidth yang diperlukan untuk melayani pelanggan di DKI Jakarta adalah 8.682,8216 Mbps.

\subsubsection{Kebutuhan Bandwidth untuk}

\section{Telephony}

Dengan asumsi yang telah dipaparkan seluruh pelanggan mobile WiMAX menggunakan handsetnya untuk melakukan layanan voice, maka jumlah pengguna yang berpotensi melakukan panggilan melalui handset adalah 595.690 orang dengan perincian sebagai berikut.

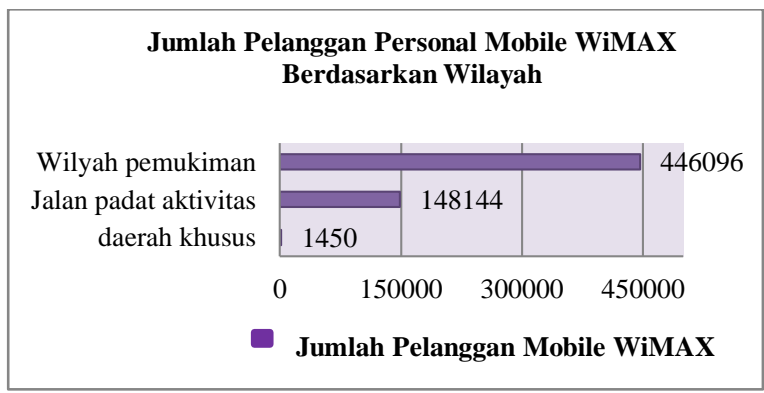

Gambar 9 Grafik Jumlah Pelanggan Personal Mobile WiMAX Berdasarkan Wilayah

Hasil perhitungan jumlah pelanggan personal Mobile WiMAX berdasarkan wilayah tersebut didapat dari penjumlahan pada tiap-tiap pelanggan personal berdasarkan wilayahnya. Sehingga mendapatkan hasil total pelanggan personal tiap wilayah.

Jumlah pengguna layanan telephony residensial adalah $25 \%$ dari pelanggan residensial. Sebagai contoh perhitungan, digunakan kecamatan Menteng dengan jumlah pelanggan 2.654 rumah.

$$
\begin{gathered}
\text { jmlh pengguna voice }=2.654 \times 0,25 \\
=664 \text { pengguna }
\end{gathered}
$$

Diketahui bahwa jumlah pengguna layanan voice di wilayah permukiman adalah 39.764 orang. Data pengguna voice untuk Pengguna Residensial per Kecamatan dapat dilihat pada grafik 4.7 berikut.

Dengan asumsi bahwa dalam satu jam sibuk, pengguna layanan voice yang 
menggunakan fasilitas kantor adalah 150 orang per gedung untuk kantor besar yang berada di wilayah segitiga emas dan 50 orang per gedung untuk kantor di wilayah lainnya dan di bangunan industri.

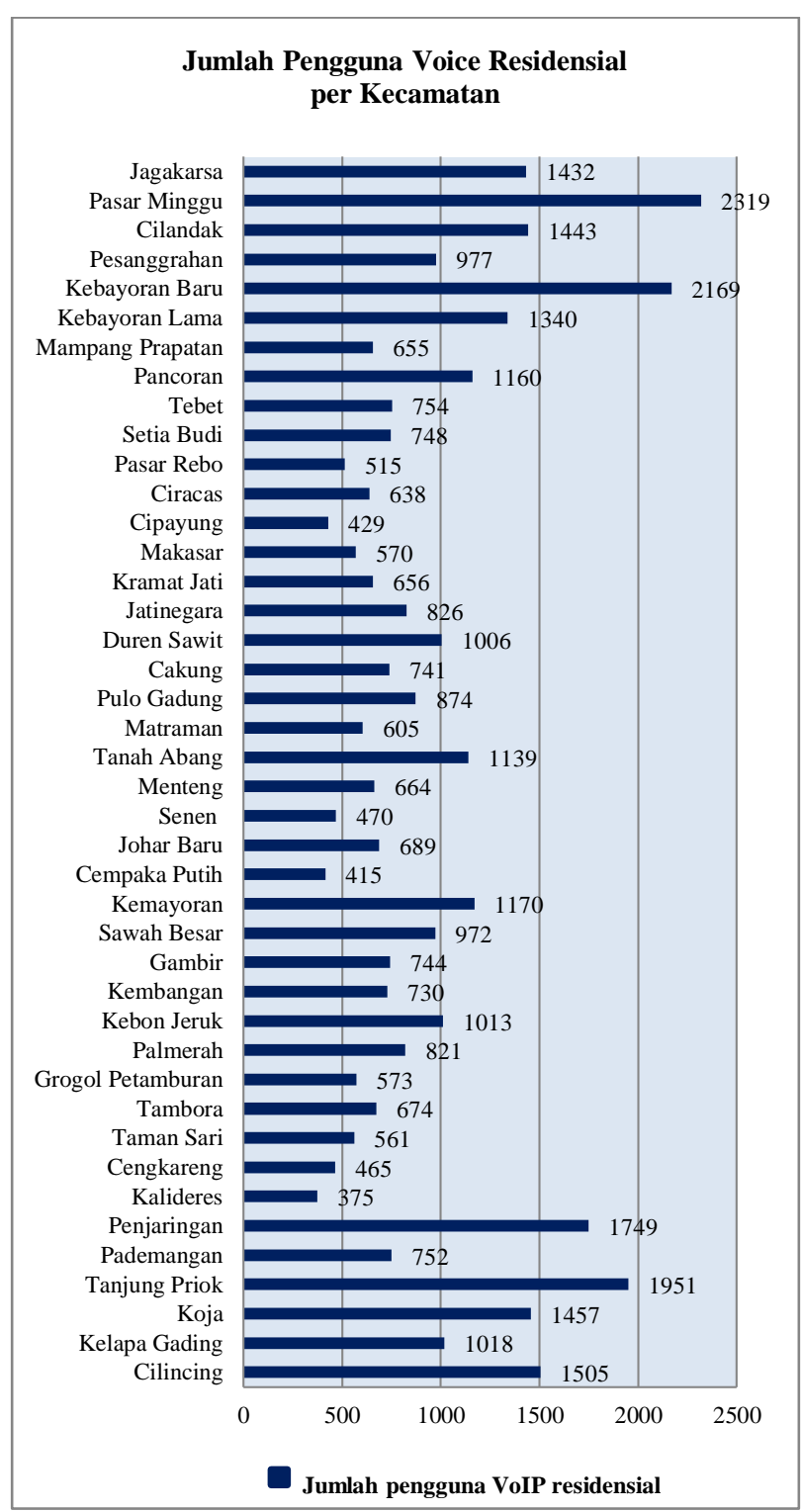

Gambar 10 Grafik Jumlah Pengguna Voice Residensial per Kecamatan

Sebagai contoh perhitungan, digunakan Jalan Gatot Subroto yang termasuk dalam kawasan segitiga emas dengan jumlah pelanggan 40 gedung.

$$
\begin{array}{r}
\text { jmlh pengguna voice }=150 \times 40 \\
=6.000 \text { pengguna }
\end{array}
$$

Maka jumlah pengguna yang berpotensi melakukan panggilan pada jalan padat aktivitas adalah 36.600 orang dengan perincian sebagai berikut.

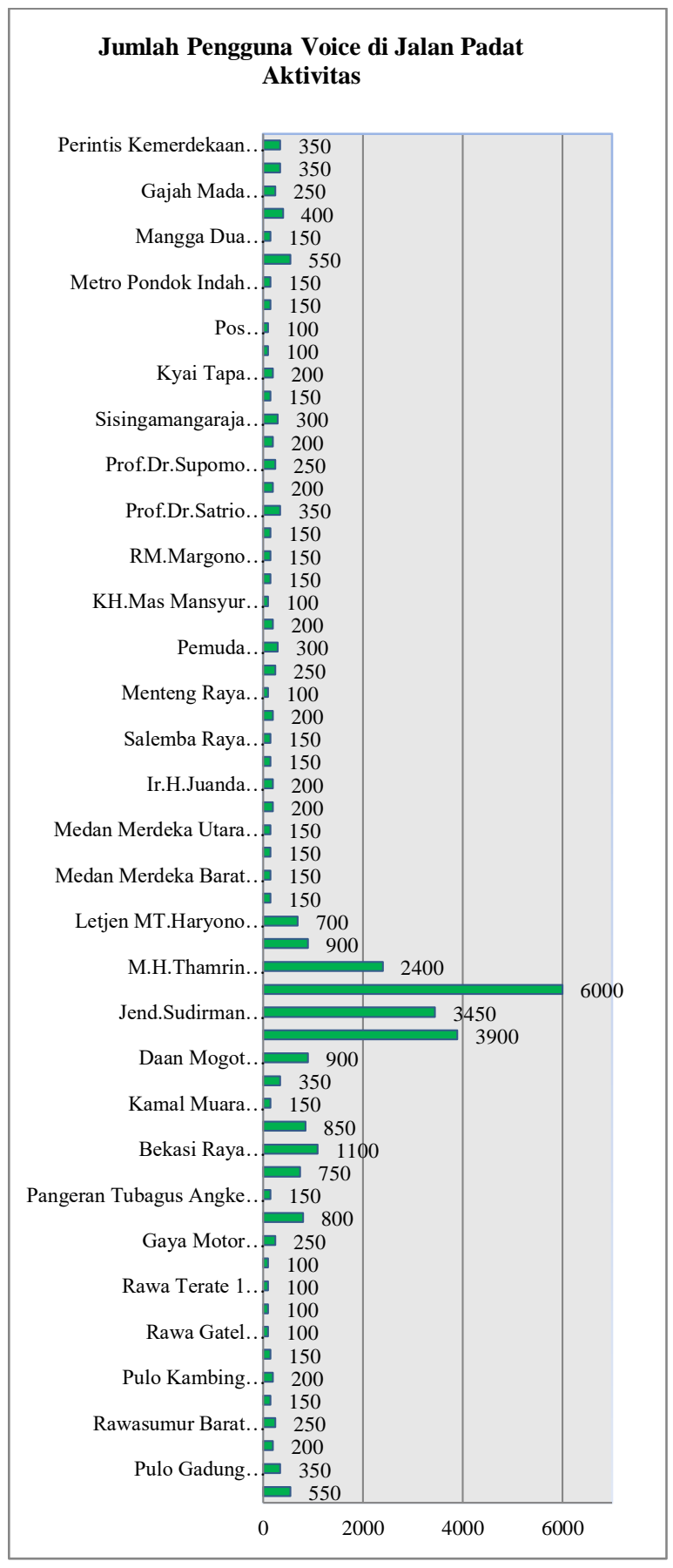




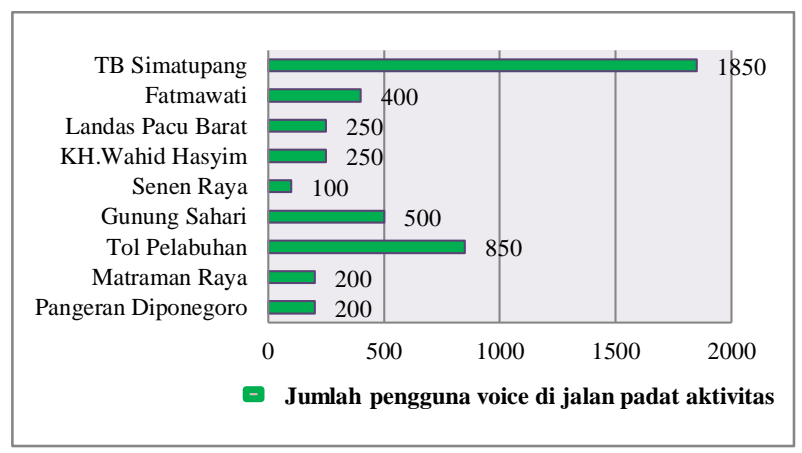

Gambar 11 Grafik Jumlah Pengguna Voice

Fasilitas Kantor di Jalan Padat Aktivitas

Berdasarkan gambar grafik 9, grafik 10, dan grafik 11, diketahui bahwa pengguna layanan voice menggunakan WiMAX berjumlah 672.054 orang. Jika waktu bicara rata-rata seorang pelanggan adalah 3 menit, maka:

Intensitas trafik per user $=\lambda \times \mathrm{h}$

$$
\begin{aligned}
& =1 \times \frac{180 \mathrm{dtk}}{3.600 \mathrm{dtk}} \\
& =0,05 \text { Erlang }
\end{aligned}
$$

Dengan total pengguna layanan voice sejumlah 672.054 orang, diperoleh

Intensitas trafik per user

$$
\begin{aligned}
& =0,05 \text { Erlang } \times 672.054 \\
& =33602,7 \text { Erlang }
\end{aligned}
$$

Untuk menghitung bandwidth voice, data yang diperlukan adalah jumlah kanal. Karena wilayah DKI Jakarta terbagi menjadi beberapa sel dan setiap selnya terbagi menjadi tiga sektor, data yang diperlukan adalah jumlah kanal per sektor. Untuk mengetahui jumlah kanal per sektor, diperlukan data jumlah base station, sedangkan jumlah base station belum diketahui karena bandwidth voice belum diketahui. Sehingga cara yang dilakukan untuk menghitung bandwidth voice sekaligus menghitung jumlah base station adalah dengan proses iterasi.

Langkah-langkah perhitungan shares bandwidth untuk layanan telephony, yaitu:

1. Menghitung jumlah sel, dengan cara membagi total shared bandwidth dengan bandwidth yang dapat ditangani oleh satu sel. Sesuai asumsi yang telah dipaparkan pada bab 4, bandwidth yang dapat dilayani oleh satu sel adalah 90 Mbps.

$$
\text { Jumlah sel }=\frac{8.682,8216}{90}=97 \mathrm{Sel}
$$

2. Menghitung intensitas trafik per sektor, diperoleh dengan cara membagi intensitas trafik total dengan jumlah sektor total.

$$
\begin{aligned}
& \text { Intensitas traf } i k \text { per sektor }=\frac{33602,7}{3 \times 97} \\
& =115,473 \text { Erlang } \\
& \approx 116 \text { Erlang }
\end{aligned}
$$

Untuk memenuhi persyaratan GoS $2 \%$, maka:

Jumlah kanal yang diperlukan

$$
=129 \text { kanal per sektor }
$$

3. Menghitung bandwidth voice per sector, Jika satu kanal voice membutuhkan bandwidth 20 kbps, maka: 
bandwidth voice per sektor

$$
\begin{aligned}
& =129 \times \frac{20}{1.024} \\
& =2,5 \mathrm{Mbps}
\end{aligned}
$$

4. Menghitung total bandwidth yang diperlukan untuk melayani pengguna layanan telephony adalah

Total bandwidth voice $=2,5 \times 3 \times 97$

$$
=728 \mathrm{Mbps}
$$

Bandwidth total yang diperlukan untuk melayani kebutuhan shared bandwidth dan bandwidth voice adalah

Total bandwidth $=8.682,8216+728$

$$
=9.410,8216 \mathrm{Mbps}
$$

Langkah perhitungan yang kedua ini sama dengan langkah perhitungan yang pertama, karena perhitungan ini menggunakan proses iterasi. Langkah perhitungannya sebagai berikut:

1. Menghitung jumlah sel, dengan cara membagi total shared bandwidth dengan bandwidth yang dapat ditangani oleh satu sel. Sesuai asumsi yang telah dipaparkan, bandwidth yang dapat dilayani oleh satu sel adalah 90 Mbps.

Jumlah sel $=\frac{9.410,8216}{90}=105$ Sel

2. Menghitung intensitas trafik per sektor, diperoleh dengan cara membagi intensitas trafik total dengan jumlah sektor total.

$$
\begin{aligned}
& \text { Intensitas trafik per sektor }=\frac{33602,7}{3 \times 105} \\
& \quad=106,675 \text { Erlang } \\
& \quad \approx 107 \text { Erlang }
\end{aligned}
$$

Untuk memenuhi persyaratan GoS 2\%, maka:

Jumlah kanal yang diperlukan

$$
=120 \text { kanal per sektor }
$$

3. Menghitung bandwidth voice per sector, Jika satu kanal voice membutuhkan bandwidth $20 \mathrm{kbps}$, maka:

bandwidth voice per sektor

$$
\begin{aligned}
& =120 \times \frac{20}{1.024} \\
& =2,34375 \mathrm{Mbps}
\end{aligned}
$$

4. Menghitung total bandwidth yang diperlukan untuk melayani pengguna layanan telephony adalah

Total bandwidth voice $=2,34375 \times 3 \times 107$

$$
=752,34375 \mathrm{Mbps}
$$

Bandwidth total yang diperlukan untuk melayani kebutuhan shared bandwidth dan bandwidth voice adalah

Total bandwidth $=8.682,8216+752,34375$

$$
=9.435,16535 \mathrm{Mbps}
$$

Dari hasil iterasi, jumlah bandwidth yang dibutuhkan untuk melayani pengguna layanan voice adalah 752,34375 Mbps. Kebutuhan bandwidth total untuk melayani 
pelanggan WiMAX di wilayah DKI Jakarta adalah 9.435,16535 Mbps.

\subsection{Perhitungan Jumlah Base Station}

Metode perhitungan kebutuhan jumlah base station terdiri dari dua jenis, yaitu perhitungan berdasarkan coverage dan perhitungan berdasarkan kapasitas.

\subsubsection{Perhitungan Jumlah Base Station}

\section{Berdasarkan}

\section{Coverage}

Dalam melakukan perhitungan jumlah base station berdasarkan coverage, data yang harus dimiliki adalah luas wilayah DKI Jakarta dan luas sel yang dapat dilingkupi oleh sebuah base station. Sesuai dengan batasan masalah pada bab 1, tugas akhir ini hanya perencanaan sel pada lima kotamadya di DKI Jakarta dan tidak membahas perencanaan untuk wilayah Kepulauan Seribu. Luas wilayah daratan DKI Jakarta tanpa Kepulauan Seribu adalah 649,71 km².

Untuk mengetahui luas sel, terlebih dahulu harus diketahui jarak jangkau maksimum suatu base station. Faktor penting dalam menentukan jarak jangkau suatu base station adalah nilai path loss. Path loss merupakan perbandingan antara daya pancar dengan daya terima. Suatu sinyal dapat diterima dengan baik jika di sisi penerima, sinyal tersebut memenuhi nilai Signal to Noise Ratio (SNR) tertentu. Pada standar IEEE 802.16e, modulasi yang digunakan pada pinggir sel adalah QPSK. Untuk modulasi QPSK, SNR yang diperlukan adalah 3,49 dB.

Selain mengetahui SNR yang dibutuhkan, parameter lain yang perlu diketahui untuk menghitung nilai path loss adalah parameter link budget. Parameter yang digunakan pada perencanaan ini adalah sebagai berikut

Tabel 2 Parameter Link Budget Downlink

\begin{tabular}{|c|c|}
\hline \multicolumn{2}{|l|}{ Base Station } \\
\hline Daya output transmitter $\left(\mathrm{P}_{\mathrm{TX}}\right)$ & $43 \mathrm{dBm}$ \\
\hline Gain antenna $\left(\mathrm{G}_{\mathrm{Tx}}\right)$ & $15 \mathrm{dBi}$ \\
\hline Loss transmitter $\left(\mathrm{L}_{\mathrm{Tx}}\right)$ & $0,7 \mathrm{~dB}$ \\
\hline \multicolumn{2}{|l|}{ Mobile Station } \\
\hline Gain receiver $\left(\mathrm{G}_{\mathrm{Rx}}\right)$ & $0 \mathrm{dBi}$ \\
\hline Receiver noise figure & $7 \mathrm{~dB}$ \\
\hline Thermal noise & $-174 \mathrm{dBm} / \mathrm{Hz}$ \\
\hline \multicolumn{2}{|l|}{ Margin } \\
\hline Log normal fade margin & $5,56 \mathrm{~dB}$ \\
\hline Fast fading margin & $2 \mathrm{~dB}$ \\
\hline Interference margin & $2 \mathrm{~dB}$ \\
\hline Building penetration loss & $10 \mathrm{~dB}$ \\
\hline
\end{tabular}

Berdasarkan parameter di atas, perhitungan yang dilakukan adalah sebagai berikut.

Bandwidth satu carrier adalah $10 \mathrm{MHz}$, sehingga

Thermal noise $=-174+10 \log _{10}\left(10.10^{6}\right)$ $=-104 \mathrm{dBm}$

$\mathrm{SNR}=\mathrm{P}_{\mathrm{Rx}}-\mathrm{N}$

Dengan $\mathrm{P}_{\mathrm{Rx}}=$ sensitivitas receiver $\mathrm{N}=$ daya noise pada receiver

$$
\begin{aligned}
\mathrm{P}_{\mathrm{Rx}}=\mathrm{SNR}+\mathrm{N} & =3,49+(-104+7) \\
& =-93,51 \mathrm{dBm}
\end{aligned}
$$

$$
\begin{aligned}
\text { Total margin } & =5,56+2+2+10 \\
& =19,56 \mathrm{~dB}
\end{aligned}
$$


Path loss $=\mathrm{P}_{\mathrm{Tx}}+\mathrm{G}_{\mathrm{Tx}}-\mathrm{L}_{\mathrm{Tx}}-\mathrm{P}_{\mathrm{Rx}}-$ margin

Path loss $=43+15-0,7-93,51-19,56$

$$
\begin{gathered}
=57,3-(-93,51)-19,56 \\
=131,25 \mathrm{~dB}
\end{gathered}
$$

Jarak jangkau suatu base station dapat dihitung dengan persamaan Erceg seperti persamaan (1). Persamaan tersebut dapat dimodifikasi menjadi

$\mathrm{d}=\mathrm{d}_{0} \cdot 10 \frac{\mathrm{PL}-20 \log \left(\frac{4 \pi \mathrm{d}_{0} \mathrm{f}}{\mathrm{c}}\right)-6 \log \frac{\mathrm{f}}{1900}+10,8 \log \frac{\mathrm{h}_{\mathrm{m}}}{2}}{10 \gamma}$

Pada perencanaan ini, wilayah Jakarta dibagi menjadi terrain A yang merupakan daerah padat dengan gedung-gedung perkantoran yang tinggi dan terrain B yang mayoritas merupakan daerah permukiman dan jarang terdapat gedung-gedung tinggi. Pembagian terrain A dan terrain B di wilayah Jakarta dapat dilihat pada gambar berikut. Wilayah yang berada di dalam kotak putih merupakan wilayah terrain A.

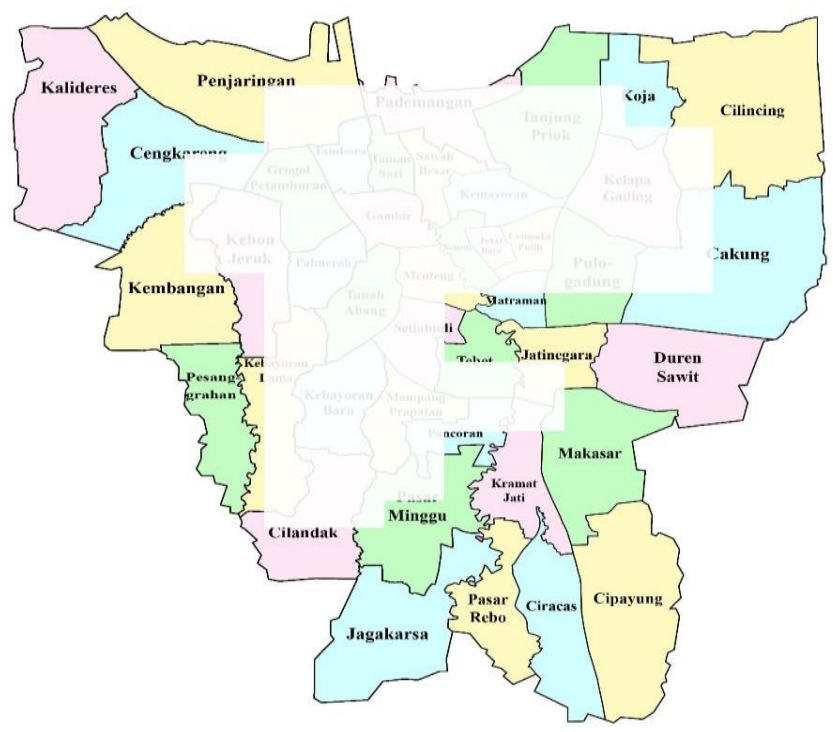

Gambar 4.9 Pembagian Wilayah Jakarta

\section{Berdasarkan Terrain}

Dengan menggunakan persamaan (3)

untuk menghitung path loss exponent terrain

A, diperoleh

$$
\gamma=4,6-0,0075.32+\frac{12,6}{32}=4,7538
$$

Sehingga radius sel pada wilayah terrain A adalah

d

$$
\begin{aligned}
& =\mathrm{d}_{0} \cdot 10 \frac{131,25-20 \log \left(\frac{4 \pi \cdot 100 \cdot 2,5 \cdot 10^{9}}{3 \cdot 10^{8}}\right)-6 \log \frac{2500}{1900}+10,8 \log \frac{1,5}{2}}{10.4,7538} \\
& =1.062 \mathrm{~m}
\end{aligned}
$$

Dengan bentuk sel heksagonal, luas suatu sel pada wilayah terrain A adalah

$$
\begin{aligned}
\mathrm{L}=\frac{3 \sqrt{3}}{2} \mathrm{~d}^{2} & =\frac{3 \sqrt{3}}{2}(1062)^{2} \\
& =2930224,67 \mathrm{~m}^{2} \\
& =2,930224 \mathrm{~km}^{2}
\end{aligned}
$$


Luas wilayah terrain A adalah 255,4375 km² sehingga kebutuhan base station pada wilayah terrain A adalah

Jumlah base station $=\frac{255,4375}{2,930224}=87,17$

$$
\approx 87 \text { base station }
$$

Sedangkan untuk terrain B, Dengan menggunakan persamaan (3) untuk menghitung path loss exponent terrain B. Maka diperoleh

$$
\gamma=4-0,0065.50+\frac{17,1}{50}=4,017
$$

Sehingga radius sel pada wilayah terrain B adalah

d

$$
\begin{aligned}
& =\mathrm{d}_{0} \cdot 10 \frac{131,25-20 \log \left(\frac{4 \pi \cdot 100 \cdot 2,5 \cdot 10^{9}}{3 \cdot 10^{8}}\right)-6 \log _{\frac{1900}{1900}+10,8 \log \frac{1,5}{2}}}{10.4,017} \\
& =1.638 \mathrm{~m}
\end{aligned}
$$

Dengan bentuk sel heksagonal, luas suatu sel pada wilayah terrain $B$ adalah

$$
\begin{aligned}
\mathrm{L}=\frac{3 \sqrt{3}}{2} \mathrm{~d}^{2} & =\frac{3 \sqrt{3}}{2}(1638)^{2} \\
& =6970752,79 \mathrm{~m}^{2} \\
& =6,970752 \mathrm{~km}^{2}
\end{aligned}
$$

Luas wilayah terrain B adalah $394,2725 \mathrm{~km}^{2}$ sehingga kebutuhan base station pada wilayah terrain B adalah

$$
\begin{gathered}
\text { Jumlah base station }=\frac{394,2725}{6,970752}=56,56 \\
\approx 57 \text { base station }
\end{gathered}
$$

Berdasarkan jangkauan sel, jumlah base station yang dibutuhkan wilayah DKI Jakarta adalah 144 base station.

\subsubsection{Perhitungan Jumlah Base Station}

\section{Berdasarkan Kapasitas}

Berdasarkan hasil perhitungan yang telah diperoleh, jumlah base station yang diperlukan untuk menangani kebutuhan shared bandwidth dan bandwidth voice di wilayah DKI Jakarta adalah

$$
\begin{aligned}
& \text { Jumlah base station }=\frac{\text { bandwidth total }}{\text { bandwidth per sel }} \\
& =\frac{9.435,16535}{90} \\
& =105 \text { base station }
\end{aligned}
$$

Berdasarkan perhitungan di atas, diketahui bahwa jumlah base station yang dibutuhkan dari sisi coverage adalah 144 base station, sedangkan jumlah base station yang dibutuhkan dari sisi kapasitas adalah 105 base station. Sehingga dapat disimpulkan bahwa jumlah base station yang harus digunakan pada penentuan lokasi base station adalah 144 base station supaya seluruh area terlingkupi.

\subsection{Penentuan Lokasi Base Station}

Penentuan lokasi base station berdasarkan hasil jumlah base stasion yang di dapatkan adalah 144 base station supaya seluruh area terlingkupi. Jumlah base station sebanyak 144 ini merupakan jumlah minimum karena syarat kebutuhan base 
station berdasarkan kapasitas pun tetap harus dipenuhi.

Sebagai contoh penentuan base station akan dilakukan di daerah yang padat aktivitasnya seperti wilayah kotamadya Jakarta Pusat (Terrain A) yang memiliki luas area paling kecil dibandingkan kotamadya lainnya di Jakarta,tetapi wilayah ini sangat padat aktivitasnya. Dengan daerah yang tidak padat aktivitasnya adalah wilayah kotamadya Jakarta Selatan dan Jakarta Timur (Terrain B) yang kebanyakan hanya wilayah pemukiman penduduk.

Berikut adalah ilustrasi penempatan 20 buah base station di wilayah padat aktivitas (Terrain A) dengan Wilayah yang tidak padat aktivitas,hanya wilayah pemukiman saja (Terrain B).

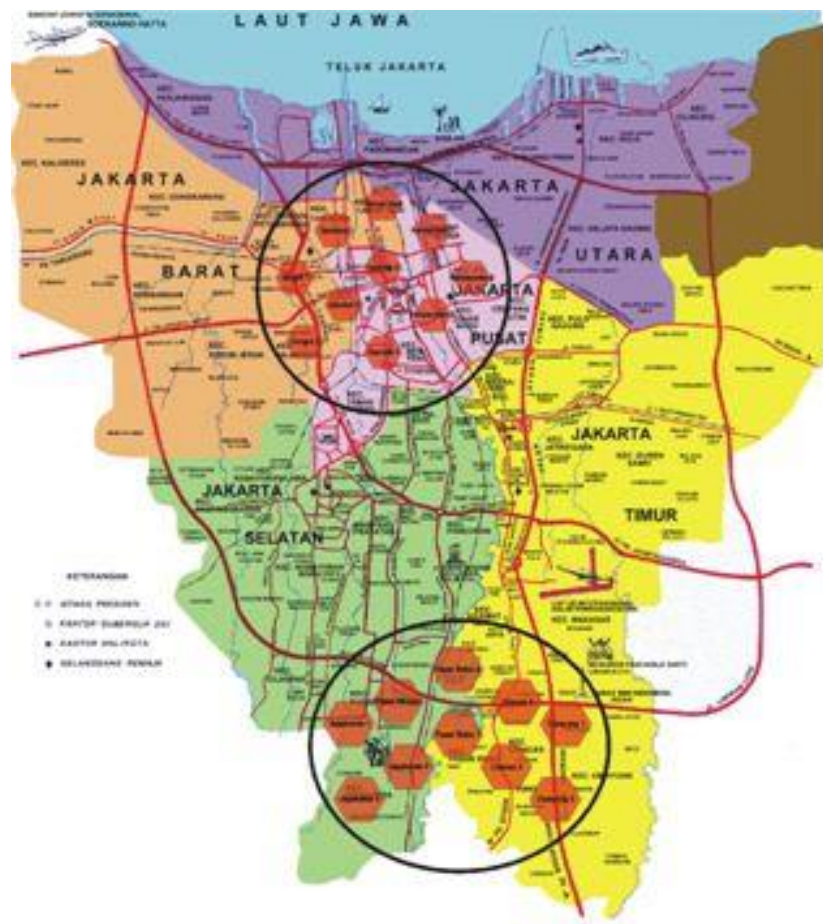

Gambar 4.10 Site Base Station di Wilayah DKI Jakarta

\section{KESIMPULAN DAN SARAN}

\subsection{Kesimpulan}

Dari hasil perencanaan dapat diambil kesimpulan sebagai berikut :

1. Total shared bandwidth yang diperlukan untuk melayani pelanggan WiMAX di DKI Jakarta adalah 8.682,8216 Mbps dengan perincian sebagai berikut:

a. Kebutuhan shared bandwidth pelanggan residensial adalah 2.982,0375 Mbps.

b. Kebutuhan shared bandwidth pelanggan corporate adalah 732 Mbps.

c. Kebutuhan shared bandwidth pelanggan personal adalah 4.954,1991 Mbps.

d. Kebutuhan shared bandwidth di daerah khusus adalah 14,585 Mbps.

2. Bandwidth yang dibutuhkan untuk melayani pengguna layanan voice adalah 752,34375 Mbps. Kebutuhan bandwidth total untuk melayani pelanggan WiMAX di wilayah DKI Jakarta adalah 9.435,16535 Mbps.

3. Sehingga radius sel pada wilayah terrain A adalah $1.062 \mathrm{~m}$. Dengan bentuk sel heksagonal, luas suatu sel pada wilayah terrain A adalah 2,930224 $\mathrm{km}^{2}$. Sedangkan untuk radius sel pada wilayah terrain B adalah $1.638 \mathrm{~m}$. Dengan bentuk sel heksagonal, luas suatu sel pada wilayah terrain B adalah $6,970752 \mathrm{~km}^{2}$.

4. Jumlah base station yang dibutuhkan untuk melayani pelanggan WiMAX di DKI Jakarta jika dihitung dari sisi kapasitas adalah 105 base station, sedangkan jumlah base station 
yang dibutuhkan jika dihitung dari sisi coverage adalah 144 base station. Sehingga dapat disimpulkan bahwa jumlah base station yang harus digunakan pada penentuan lokasi base station adalah 144 base station supaya seluruh area terlingkupi.

\subsection{Saran}

Beberapa hal yang perlu dilakukan untuk pengembangan selanjutnya antara lain:

1. Pemetaan sel hendaknya dilakukan lebih akurat lagi.

2. Dalam perencanaan di lapangan hendaknya dilakukan survey lapangan untuk mengetahui kondisi real, terutama untuk penentuan lokasi base station yang akan di bangun.

3. Dalam memperhitungkan persentase pelanggan perlu dilakukan survey terhadap penduduk Jakarta yang menggunakan jaringan mobile WiMAX supaya diperoleh asumsi yang lebih akurat.

4. Dalam perencanaan real hendaknya dilakukan estimasi kebutuhan throughput per pelanggan secara akurat.

5. Dari penelitian ini diharapkan menjadi salah satu dasar agar perusahaan lebih memperhatikan kebutuhan BTS yang akan direncanakan dan melakukan pemeliharaan BTS tersebut agar tetap terjaga sampai beberapa tahun yang akan datang.

\section{DAFTAR PUSTAKA}

Badan Pusat Statistik DKI Jakarta. 2009. Jakarta Dalam Angka 2009.

Departemen Pekerjaan Umum DKI Jakarta. Data Panjang Ruas Jalan di Wilayah DKI Jakarta.

Ditjen Postel dan Depkominfo. "Penataan Spektrum Frekuensi Radio Layanan Akses Pita Lebar Berbasis Nirkabel”. November 2006.

Gunadi Dwi Hantoro. "Mempelajari WiMAX Secara Tutorial dan Visual”. Informatika. Bandung. 2008.

Gunawan Wibisono dan Gunadi Dwi Hantoro. "WiMAX : Teknologi Broadband Wireless Access (BWA), Kini dan Masa Depan”. Informatika. 2006.

J. G. Andrews, A. Ghosh, R. Muhamed. Fundamentals of WiMAX: Understanding Broadband Wireless Networking. Prentice-Hall. 2007.

Natanael Makarios. "Prakiraan Kebutuhan Akses Broadband dan Perencanaan Jaringan Mobile WiMAX untuk Kota Bandung”. Laporan Tugas Akhir Sekolah Teknik Elektro dan Informatika, Institut Teknologi Bandung. 2007.

Puspito, Sigit W.J. 1999. "Mengenal Teknologi Orthogonal Frequency Division Multiplexing (OFDM) pada Komunikasi Wireless", Elektro Indonesia, Nomor 241999. 
T. S. Rappaport. Wireless Communications:

Principles and Practice, Second Edition.

Prentice-Hall. 2002.

WiMAX Forum. "Fixed, nomadic, portable and mobile applications for 802.16-2004 and 802.16e WiMAX networks". November 2005.

WiMAX Forum. "Mobile WiMAX - Part I: $A$ Technical Overview and Performance Evaluation". Agustus 2006.

WiMAX Forum. "WiMAX's Technology for LOS and NLOS Environtments". Agustus 2004.

Wei Chen. "Time Frequency-Selective Channel Estimation of OFDM System". Proquest Company. April 2006.

http://www.dailywireless.org/2004/11/24/wifi-

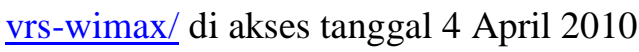
Pukul 16.00 WIB. 